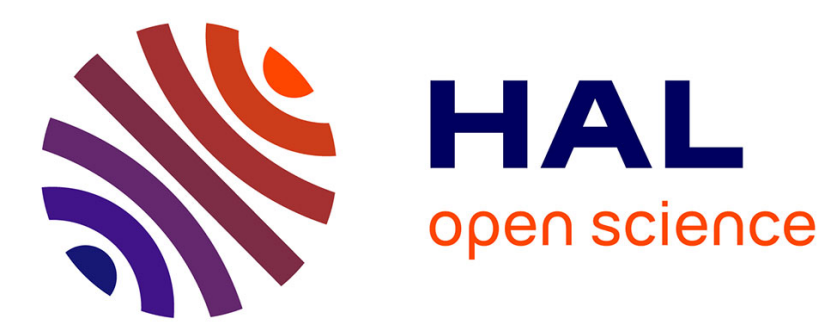

\title{
Use of co-grinding as a solvent-free solid state method to synthesize dibenzophenazines
}

Leslie Carlier, Michel Baron, Alain Chamayou, Guy Couarraze

\section{To cite this version:}

Leslie Carlier, Michel Baron, Alain Chamayou, Guy Couarraze. Use of co-grinding as a solvent-free solid state method to synthesize dibenzophenazines. Tetrahedron Letters, 2011, 52 (36), p. 4686-4689. 10.1016/j.tetlet.2011.07.003 . hal-01631590

\section{HAL Id: hal-01631590 https://hal.science/hal-01631590}

Submitted on 8 Nov 2019

HAL is a multi-disciplinary open access archive for the deposit and dissemination of scientific research documents, whether they are published or not. The documents may come from teaching and research institutions in France or abroad, or from public or private research centers.
L'archive ouverte pluridisciplinaire HAL, est destinée au dépôt et à la diffusion de documents scientifiques de niveau recherche, publiés ou non, émanant des établissements d'enseignement et de recherche français ou étrangers, des laboratoires publics ou privés. 


\title{
Use of co-grinding as a solvent-free solid state method to synthesize dibenzophenazines
}

\author{
Leslie Carlier $^{\mathrm{a}, *}$, Michel Baron ${ }^{\mathrm{a}}$, Alain Chamayou ${ }^{\mathrm{a}}$, Guy Couarraze ${ }^{\mathrm{b}}$
}

${ }^{a}$ Ecole des Mines d'Albi-Carmaux, FRE CNRS 3213, Laboratoire RAPSODEE, PRES Université de Toulouse, Campus Jarlard, Route de Teillet, 81013 ALBI Albi CT Cedex09, France ${ }^{\mathrm{b}}$ Université Paris-Sud 11, UMR CNRS 8612, Laboratoire de Physique Pharmaceutique, Rue Jean Baptiste Clément, 92296 Châtenay Malabry Cedex, France

\section{Keywords:}

Solid-phase synthesis

Green chemistry

Dibenzophenazines

Pyrido-quinoxaline

Organic mechanochemistry

\section{A B S T R A C T}

Many synthetic methods exist for dibenzoquinoxalines but only a few for dibenzophenazines and their aza derivatives and even less are 'green'. Some dibenzophenazines and dibenzopyridoquinoxaline have been efficiently obtained with good to excellent yield by a very simple method which does not require use of solvent or catalyst. Solid phase synthesis using co-grinding presents thus many advantages in developing greener synthetic organic pathways.

\section{Introduction}

The overall reduction of solvent use is a key goal in the chemical industry, where more sustainable processes are needed and especially in the pharmaceutical industry in which solvent and process greenness scoring methods are used for evaluating fine chemical and drug production. It has become clear that the producers have to reduce waste drastically. Environmental restrictions continue to increase making unavoidable the use of greener chemistry.

Nowadays, a high percentage of the active pharmaceutical ingredients produced are heterocyclic, with a majority of being nitrogen heterocycles. Many such ingredients mimic the structure of biologically active molecules like pyrimidine or purine bases of nucleic acids, the main constituents of which are nitrogen heterocycles. Natural products, such as aspergillic acid ${ }^{1,2}$ (antibiotic isolated from Aspergillus flavus efficient on gram positive bacteria) and echinomycin ${ }^{3}$ (antibiotic very efficient on gram-positive bacteria like Streptococcus constituted of two quinoxaline rings) can also be placed in this category. In fact, several quinoxaline based molecules obtained synthetically showed biological activities ${ }^{4-6}$ in particular antitumor ${ }^{7-9}$ and antibacterial. ${ }^{10,11}$

Some quinoxaline based molecules such as dibenzophenazines have other applications. They can be chemical moieties of mesogeneous liquid crystals (polymers) $)^{12,13}$ and some pyridophenazines

\footnotetext{
* Corresponding author. Fax: +330563493025.

E-mail address: leslie.carlier@mines-albi.fr (L. Carlier).
}

can be used as ligands for $\operatorname{Re}(\mathrm{I})^{14}$ with the complexes having interesting luminescence properties.

For all these reasons, aromatic diaza compounds were chosen as a synthetic target. These molecules are classically synthesized by a solvent route in refluxing ethanol or acetic acid for several hours. A plethora of methods exist and most of them that increase the yield rely on the use of catalysts like common Lewis acids, $\mathrm{I}_{2}{ }^{15}$ gallium(III) triflate, ${ }^{16}$ or sulfated titania. ${ }^{17}$ Other procedures do not use any catalyst but need microwave heating. ${ }^{18}$ The aim of this work is to present another sustainable synthetic model. Co-grind-

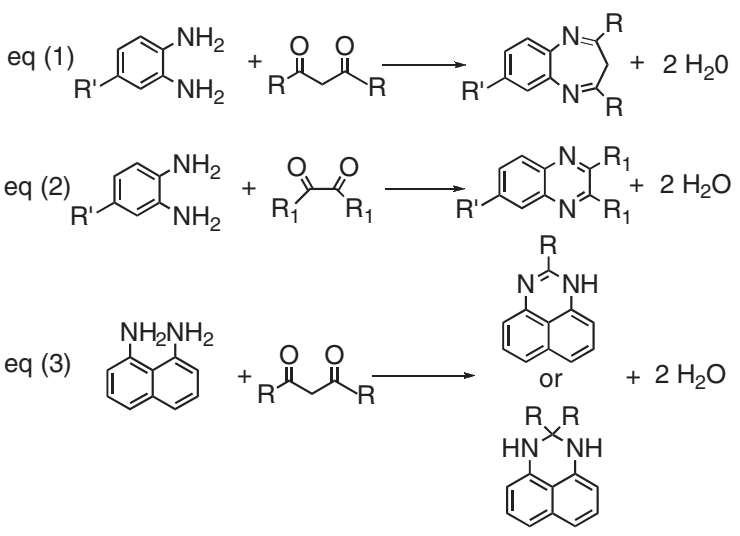

Scheme 1. Reactions between diamines and 1,2 or 1,3 dicarbonyls. 
ing with a vibrating ball-mill is used and allowed to avoid solvent use and, in some cases, purification steps. ${ }^{19-22}$ This solid-state synthetic pathway has been developed for only a few organic molecules. ${ }^{23,24}$ Benzo $[b]$ phenazine formation has been described by Zefirov ${ }^{25}$ starting from unsubstituted reactants.

Solid phase components with high melting points are required in order to avoid liquid formation during grinding (a phase change may introduce other non-desirable products). The main advantage with this kind of process is that the compounds do not need to be soluble in any solvent to allow reaction.

In this Letter, reactions at atmospheric pressure and room temperature in order to obtain diaza heterocycles, such as perimidines, quinoxalines, dibenzophenazines, or dibenzopyrazines by a greener route are presented.

\section{Results and discussion}

The reaction of a 1,2 or 1,3-dione with a 1,2 or 1,3-diamine classically leads to some perimidines, ${ }^{26}$ quinoxalines, ${ }^{18}$ or phenazines $^{25}$ according to the equations in Scheme 1. A new approach using solid-solid and solvent-free process was applied to these well-known syntheses.

Concerning the reactions described in Scheme 1, the diamines used are described in Table 1 with their melting points. In Scheme 1 (Eqs. 1 and 3), the 1,3-dione was 1,3-diphenyl-1,3-propanedione (mp: $178-179^{\circ} \mathrm{C}$ ).

Some trials with the diamines were performed using pyrocatechol $\left(\mathrm{mp}=101^{\circ} \mathrm{C}\right)$ as the potential precursor of the 1,2-dione after in-situ oxidation.

Table 1

Dibenzophenazines and aza analog observed

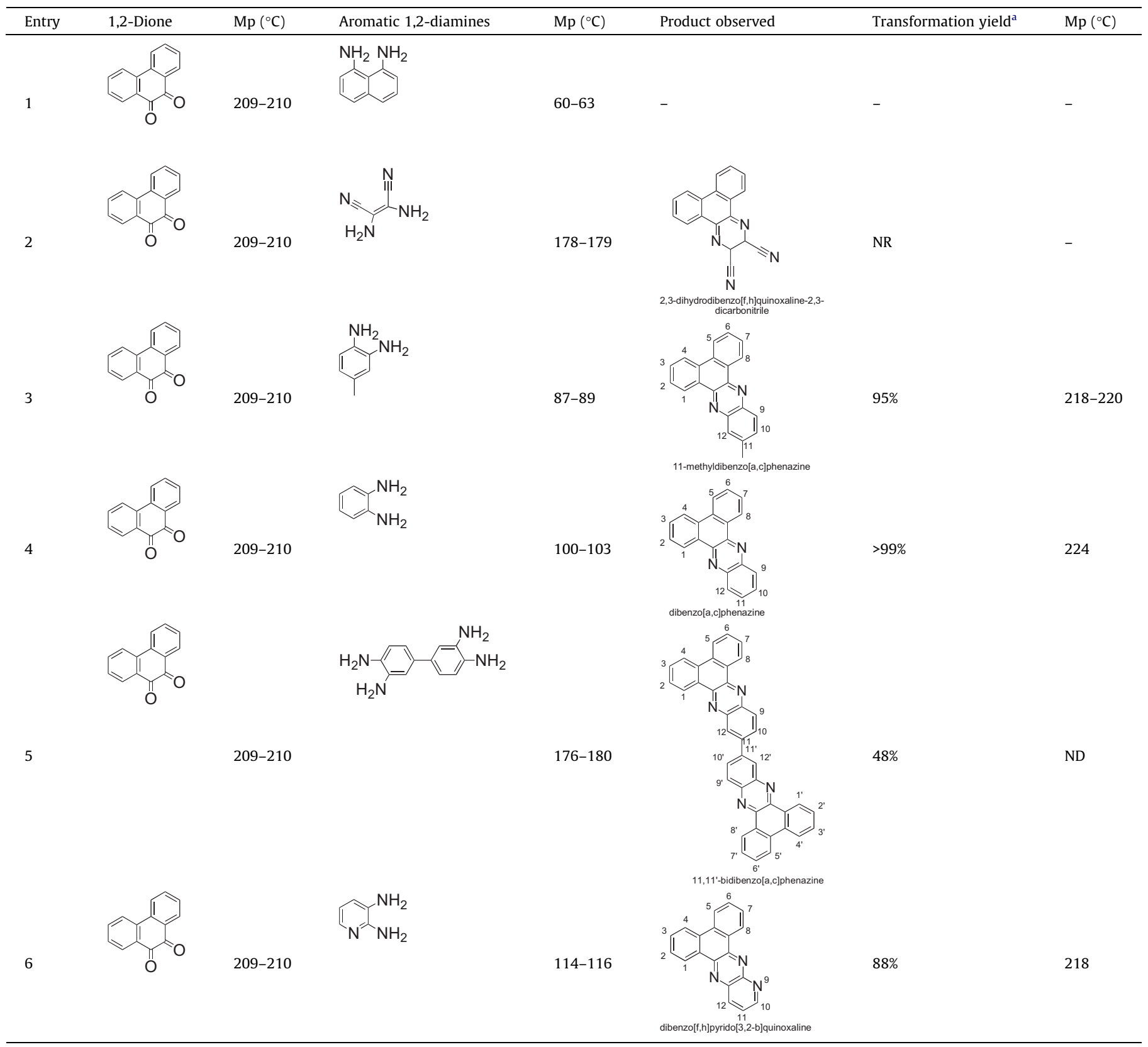

\footnotetext{
a Based on default reactant.
} 


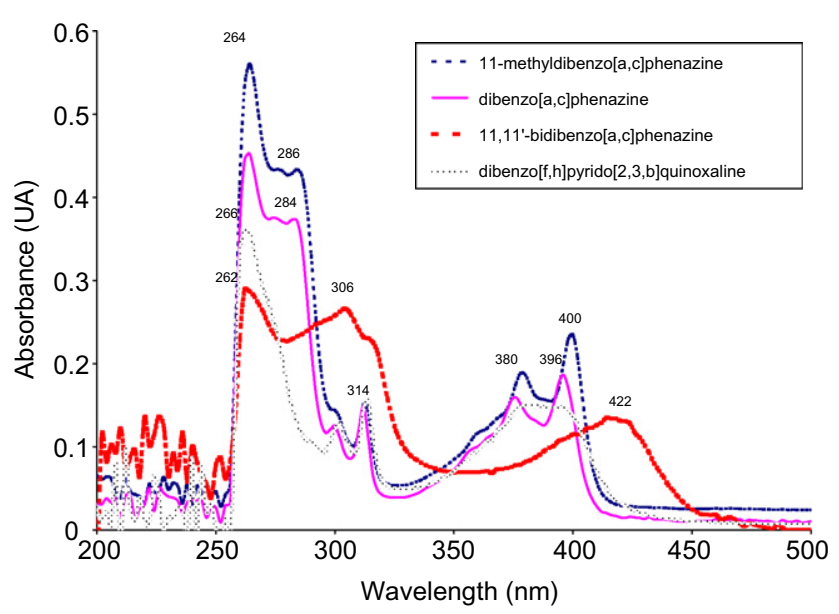

Figure 1. UV absorbance spectra for the phenazine derivatives.

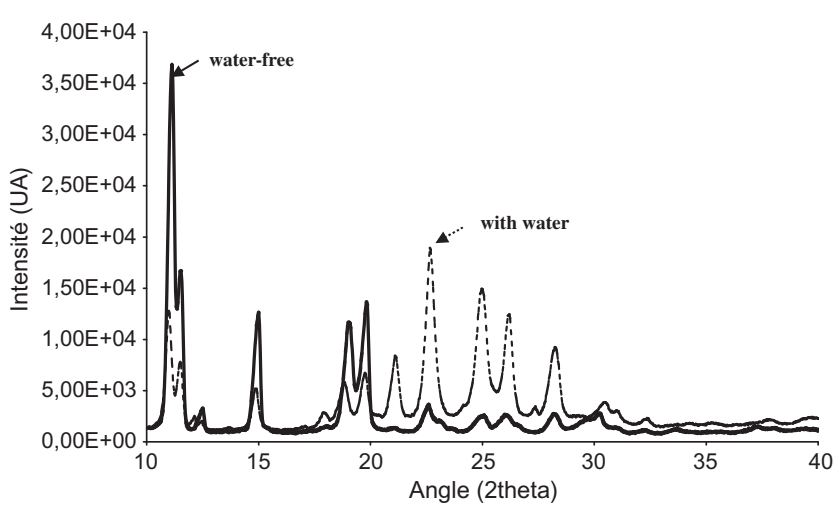

Figure 2. Comparison by XRD analysis of hydrated and non-hydrated 11methyldibenzo[a,c]phenazine.

In the literature, the selected 1,2-dione is usually benzil. In this work, phenanthrene-9,10-dione has been chosen for its higher thermal stability and higher melting point $\left(209-210{ }^{\circ} \mathrm{C}\right)$ despite a lower electrophilic character of the carbonyl carbon. ${ }^{27}$

The general procedure used for the experiments is developed in the Note section. ${ }^{28}$ Only the reactions in which the phenanthrene9,10-dione and aromatic 1,2-diamines were involved, gave positive results (Scheme 1, Eq. 2) leading to the formation of phenazine derivatives. The results are summarized in Table $1 .{ }^{29}$ All products were characterized by ${ }^{1} \mathrm{H}$ NMR, IR, and UV spectroscopy. IR spectra show the disappearance of the characteristic bands of primary amines (a symmetrical doublet around $3350 \mathrm{~cm}^{-1}$ of medium intensity) and of ketone $\left(1674 \mathrm{~cm}^{-1}\right.$ of very strong intensity due to $\mathrm{C}=\mathrm{O}$ stretching vibration and reveals the presence of an orthoquinone). All the desired compounds present the characteristic bands of the phenazine structure that are observed at 3500$3150 \mathrm{~cm}^{-1}\left(\mathrm{~N}-\mathrm{H}\right.$ stretching vibration) and $3070-3050 \mathrm{~cm}^{-1}(\mathrm{C}-\mathrm{H}$ stretching vibration).

The UV spectra show mainly three bands. A red shift is observed for the 11,11'-bidibenzo[a,c]phenazine and can be explained by the increase in conjugation in the product (Fig. 1).

The synthesis of benzodiazepines is not energetically favored since the 6-member rings are more stable and easier to synthesize. In the same way, even if a 1:1 molar ratio of reactants was used in entry 5 , only the totally cyclized product was observed.

Only the aromatic 0 -diamines allow us to obtain the quoted products. In entry 2 , none of the products is observed because the diamine is not aromatic and the cyano group is strongly electron-withdrawing which disabled the nitrogen doublets.
In entry 4 , an excellent yield was observed with a pure crude product according to GC-MS and ${ }^{1} \mathrm{H}$ NMR spectra. The presence of another substituent group on the aromatic nucleus of the diamine decreases the yield. The use of a pyrido electron acceptor heterocycle as the 0 -diamino aromatic reagent lowers the electronic density of the amino groups and the yield of the reaction is decreased. The same phenomenon is found in entry 5 .

Electron-donating groups favored the formation of the dibenzo[a,c]phenazine to give quantitative yields. In contrast, electron-withdrawing groups gave slightly lower yields. In addition, the reactant biphenyl-3,3',4,4'-tetraamine or 3,3'-diaminobenzidine and the product have very low solubility. This method thus gave us access to molecules with very low solubilities.

Further analyses were performed with the 11-methyldibenzo[a,c]phenazine. XRD analysis and comparison between products obtained by the classical solvent way (EtOH reflux then evaporation under reduced pressure) and by grinding have allowed us to determine that the product obtained by co-grinding is hydrated and is a pseudo-polymorph since the XRD shows some differences between the products (hydrated and non-hydrated) (Fig. 2).

\section{Conclusion}

We successfully developed a simple, efficient, and eco-friendly synthetic pathway, which allows the use of poorly soluble molecules and gives direct access to hydrates, which have a different crystalline structure. This is particularly interesting since the pseudo-polymorphs, like salts, can modify the bioavailability of a pharmaceutical product. Another synthetic step is thus avoided. This is the first time that these dibenzophenazines were obtained in good yield with a solvent-free method.

In conclusion, a green, atom-economical, and efficient approach to the synthesis of pyrazines has been developed. This method can be used as a quick screening synthesis method giving access to new compounds sometimes not accessible directly with another synthetic way.

The sample size allows initial pharmacological, biological, chemical, and physical characterization of the product.

\section{Acknowledgments}

The authors thank Eric Deydier and Catherine Audin for the ${ }^{1} \mathrm{H}$ NMR spectra and Céline Boachon for the DSC-TGA experiments.

\section{References and notes}

1. White, E. C.; Hill, J. H. J. Bacteriol. 1943, 45, 433-443.

2. Jones, H.; Rake, G.; Hamre, D. M. J. Bacteriol. 1943, 45, 461-469.

3. Dell, A.; Williams, D. H.; Morris, H. R.; Smith, G. A.; Feeney, J.; Roberts, G. C. K. J. Am. Chem. Soc. 1975, 97, 2497-2502.

4. Gavara, L.; Saugues, E.; Alves, G.; Debiton, E.; Anizon, F.; Moreau, P. Eur. J. Med. Chem. 2010, 45, 5520-5526.

5. Sakata, G.; Makino, K.; Kurasawa, Y. Heterocycles 1988, 27, 2481-2515.

6. Bhosale, R. S.; Sarda, S. R.; Ardhapure, S. S.; Jadhav, W. N.; Bhusare, S. R.; Pawar, R. P. Tetrahedron Lett. 2005, 46, 7183-7186.

7. Renault, J.; Baron, M.; Mailliet, P.; Giorgi-Renault, S.; Paoletti, C.; Cros, S. Eur. J. Med. Chem. 1981, 16, 545-550.

8. He, W.; Myers, M. R.; Hanney, B.; Spada, A. P.; Bilder, G.; Galzcinski, H.; Amin, D.; Needle, S.; Page, K.; Jayyosi, Z.; Perrone, M. H. Bioorg. Med. Chem. Lett. 2003, 13, 3097-3100

9. El-Dean, A. M. K.; Geies, A. A. Heterocycl. Commun. 1998, 4, 367-374.

10. Silva, R. S.; Pinto, M. D. C. F.; Goulart, M. O.; de Souza Filho, J. D.; Neves, I., Jr.; Lourenco, M. C. S.; Pinto, A. V. Eur. J. Med. Chem. 2009, 44, 2334-2337.

11. Glazer, E.; Chappel, L. J. Med. Chem. 1982, 25, 766-769.

12. Babuin, J.; Foster, J.; Williams, V. E. Tetrahedron Lett. 2003, 44, 7003-7005.

13. Gautrot, J. E.; Hodge, P. Polymer 2007, 48, 7065-7077.

14. Yeo, B. R.; Hallett, A. J.; Kariuki, B. M.; Pope, S. J. Polyhedron 2010, 29, 1088 1094.

15. More, S. V.; Sastry, M.; Wang, C.; Yao, C. Tetrahedron Lett. 2005, 46, 6345-6348.

16. Cai, J.; Zou, J.; Pan, X.; Zhang, W. Tetrahedron Lett. 2008, 49, 7386-7390. 
17. Krishnakumar, B.; Velmurugan, R.; Jothivel, S.; Swaminathan, M. Catal. Commun. 2010, 11, 997-1002.

18. Zhao, Z.; Wisnoski, D. D.; Wolkenberg, S. E.; Leister, W. H.; Wang, Y.; Lindsley, C. W. Tetrahedron Lett. 2004, 45, 4873-4876.

19. Kaupp, G. In Organic Solid State Reactions: 2005; pp 95-183.

20. Kaupp, G. CrystEngComm 2006, 8, 794-804.

21. Kaupp, G.; Schmeyers, J.; Boy, J. Tetrahedron 2000, 56, 6899-6911.

22. Kaupp, G.; Schmeyers, J.; Boy, J. Chemosphere 2001, 43, 55-61.

23. Kaupp, G. CrystEngComm 2009, 11, 388-403.

24. Rodriguez, B.; Bruckmann, A.; Rantanen, T.; Bolm, C. Adv. Synth. Catal. 2007, 349, 2213-2233.

25. Zefirov, N. S.; Sereda, G. A.; Volkov, V. P.; Tkachenko, S. E.; Zyk, N. V. Chem. Heterocycl. Compd. 1996, 32, 577-579.

26. Yavari, I.; Mostafavi, H.; Tahmassebi, D.; Hekmat-Shoar, R. Monatsh. Chem. 1997, 128, 675-679.

27. Muddasir, H.; Lu, P.; Wang, Z. M.; Yang, S.-M.; Yang, B.; Wang, C.-L.; Ma, Y. G. Chem. Res. Chinese universities 2009, 25, 950-956.

28. General procedure: reactions are carried out in a vibrating ball-mill Pulverisette 0 (Fritsch, Germany) in $4 \mathrm{~h}$ with an agate single ball. The reactants were introduced in equimolar ratio and in solid state (powder, flakes, etc.) under atmospheric conditions (air at room temperature and pressure). The total mass introduced in the ball-mill was $2 \mathrm{~g}$, the vibration frequency was $50 \mathrm{~Hz}$, and the vibration amplitude was $2.5 \mathrm{~mm}$. All chemicals were purchased from Aldrich and were used without any additional treatment (the purities of the reactants are technical grade and comprise of between $95 \%$ and $97 \%$ for each compound). ${ }^{1} \mathrm{H}$ NMR $(200 \mathrm{MHz})$ spectra were recorded on a BRUKER Advance 200 spectrometer with $\left(\mathrm{CD}_{3}\right)_{2} \mathrm{SO}$ as the solvent which was obtained from Eurisotop $^{\circledR}$ and tetramethylsilane (TMS) as the internal standard at $298 \mathrm{~K}$. GC-MS spectra were obtained with a Q5050A Shimadzu spectrometer with $\mathrm{CH}_{2} \mathrm{Cl}_{2}$ as the solvent and in EI mode. The injector temperature was $280^{\circ} \mathrm{C}$ and this of the detector: $300{ }^{\circ} \mathrm{C}$. The column flow was $1.4 \mathrm{~mL} / \mathrm{min}$. We used the following temperature program: $140^{\circ} \mathrm{C}$ for $4 \mathrm{~min}$ then go to $160^{\circ} \mathrm{C}$ by $30^{\circ} \mathrm{C} / \mathrm{min}$ for $4 \mathrm{~min}$ and go to $270^{\circ} \mathrm{C}$ by $30^{\circ} \mathrm{C} / \mathrm{min}$ and stay $20 \mathrm{~min}$.

Melting points were obtained on a Netzsch thermal Analysis system STA409. The study was made from $30^{\circ} \mathrm{C}$ to $500{ }^{\circ} \mathrm{C}$ with a step of $5^{\circ} \mathrm{C} / \mathrm{min}$.

UV spectra were recorded on HP8452A Diode Array spectrophotometer in precision cell made of quartz suprasil ${ }^{\circledR}$ with DMSO as the solvent with an approximate concentration of $3 \times 10^{-3} \mathrm{~g} / \mathrm{L}$.

A Fourier Transform Infrared (FTIR) spectrometer from Perkin Elmer model series 2000 was used in order to make the acquisition of the IR spectra in $\mathrm{KBr}$ Pellets.

For microanalysis: a thermoquest NA2100 elemental analyzer was used. This model was equipped with an autosampler AS2000.

XRD experiments were carried out on a X'Pert Pro system from Panalytical. To determine if the reactions occurred, ${ }^{1} \mathrm{H}$ NMR was used as an analytical technique and DSC-TGA for melting point measurements.
29. Data for 11-methyldibenzo[a,c]phenazine: yield (1.78 g, 95\%), all the analyses were purchased on the crude product. Mp: $218-220{ }^{\circ} \mathrm{C}^{1} \mathrm{H}$ NMR $\delta_{\mathrm{H}}(200 \mathrm{MHz}$; $\left.\left(\mathrm{CD}_{3}\right)_{2} \mathrm{SO} ; \mathrm{Me}_{4} \mathrm{Si}\right): 9.30 \mathrm{ppm}(2 \mathrm{H}, \mathrm{d}, 7.4 \mathrm{~Hz}, 4-\mathrm{H}$ and $5-\mathrm{H}), 8.83 \mathrm{ppm}(2 \mathrm{H}, \mathrm{d}, 8 \mathrm{~Hz}$, $1-\mathrm{H}$ and $8-\mathrm{H}), 8.27 \mathrm{ppm}(1 \mathrm{H}, \mathrm{d}, 8.6 \mathrm{~Hz}, 9-\mathrm{H}), 8.16 \mathrm{ppm}(1 \mathrm{H}, \mathrm{s}, 12-\mathrm{H}), 7.98-$ $7.81 \mathrm{ppm}(5 \mathrm{H}, \mathrm{m}, 2-\mathrm{H}, 3-\mathrm{H}, 6-\mathrm{H}$ and $7-\mathrm{H}), 2.69 \mathrm{ppm}$ (3H, s, 11-Me) MS-EI m/z: 294(M, 100\%), 147(37), 146(21), 295( $\left.\mathrm{M}^{+1}, 19\right), 133(15), 293\left(\mathrm{M}^{-1}, 11\right) \cdot v(\mathrm{KBr}) /$ $\mathrm{cm}^{-1}: 3374(\mathrm{~N}-\mathrm{H}, \mathrm{w}), 3060$ and $3037(\mathrm{C}-\mathrm{H}$, sharp doublet, w); UV (DMSO): maxima observed at $264,286,314,380,400 \mathrm{~nm}$. Anal. Calcd for $\mathrm{C}_{21} \mathrm{H}_{14} \mathrm{~N}_{2}$ : C, 85.69; H, 4.79; N, 9.52. Found: C, $85.90 \pm 0,12 ; \mathrm{H}, 4.74 \pm 0,09 ; \mathrm{N}, 9.36 \pm 0,06$. Data for Dibenzo[a,c]phenazine: yield $\left(1.77 \mathrm{~g}\right.$, >99\%). Mp: $224^{\circ} \mathrm{C}$. All the analyses were performed on the crude product. ${ }^{1} \mathrm{H}$ NMR $\delta_{\mathrm{H}}(200 \mathrm{MHz}$; $\left.\left(\mathrm{CD}_{3}\right)_{2} \mathrm{SO} ; \mathrm{Me}_{4} \mathrm{Si}\right): 9.34 \mathrm{ppm}(2 \mathrm{H}, \mathrm{dd}, 7.6 \mathrm{~Hz}, 1.8 \mathrm{~Hz}, 4-\mathrm{H}$ and $5-\mathrm{H}), 8.86 \mathrm{ppm}$ $(2 \mathrm{H}, \mathrm{dd}, 7.7 \mathrm{~Hz}, 1.4 \mathrm{~Hz}, 1-\mathrm{H}$ and $8-\mathrm{H}), 8.4 \mathrm{ppm}(2 \mathrm{H}, \mathrm{dd}, 3.4 \mathrm{~Hz}, 6.6 \mathrm{~Hz}, 9-\mathrm{H}$ and $12-\mathrm{H}), 8.04 \mathrm{ppm}(2 \mathrm{H}, \mathrm{dd}, 3.4 \mathrm{~Hz}, 6.6 \mathrm{~Hz}, 10-\mathrm{H}$ and $11-\mathrm{H}), 7.99-7.83 \mathrm{ppm}(4 \mathrm{H}$, $\mathrm{m}, 2-\mathrm{H}, 3-\mathrm{H}, 6-\mathrm{H}$ and 7-H) MS-EI $m / z$ : 280(M, 100\%), 140(47), 281( $\left.\mathrm{M}^{+1}, 21\right)$, 126(12); $v(\mathrm{KBr}) / \mathrm{cm}^{-1}: 3380(\mathrm{~N}-\mathrm{H}, \mathrm{br}, \mathrm{w}), 3059$ and $3031(\mathrm{C}-\mathrm{H}$, sharp doublet, w); UV (DMSO): maxima observed at 264, 284, 314, 378, $396 \mathrm{~nm}$. Anal. Calcd for $\mathrm{C}_{20} \mathrm{H}_{12} \mathrm{~N}_{2}$ : C, 85.69; H, 4.31; N, 9.99. Found: C, $85.78 \pm 0,15 ; \mathrm{H}, 4.31 \pm 0,11$; $\mathrm{N}, 9.91 \pm 0,13$.

Data for 11,11'-bidibenzo[a,c]phenazine: yield (0.61 g, 48\%), Mp: not observed. For analysis, the pure product was obtained after a chromatographic column with toluene/dioxane 3:1 as the eluent. The product is difficult to solubilize and DMF was used as a solvent for the column deposit to limit this one. ${ }^{1} \mathrm{H}$ NMR $\delta_{\mathrm{H}}\left(200 \mathrm{MHz} ;\left(\mathrm{CD}_{3}\right)_{2} \mathrm{SO} ; \mathrm{Me}_{4} \mathrm{Si}\right): 9.53-9.26 \mathrm{ppm}\left(4 \mathrm{H}, \mathrm{m}, 4-\mathrm{H}, 5-\mathrm{H}\right.$ and $4^{\prime}-\mathrm{H}$, $\left.5^{\prime}-\mathrm{H}\right), 8.85 \mathrm{ppm}\left(4 \mathrm{H}, \mathrm{d}, 7 \mathrm{~Hz}, 1-\mathrm{H}\right.$ and $1^{\prime}-\mathrm{H}, 8-\mathrm{H}$ and $\left.8^{\prime}-\mathrm{H}\right), 8.61-8.26 \mathrm{ppm}(4 \mathrm{H}$, $\mathrm{m}, 9-\mathrm{H}$ and $9^{\prime}-\mathrm{H}, 12-\mathrm{H}$ and $\left.12^{\prime}-\mathrm{H}\right), 8.00-7.80 \mathrm{ppm}\left(10 \mathrm{H}, \mathrm{m}, 2-\mathrm{H}\right.$ and $2^{\prime}-\mathrm{H}, 3-\mathrm{H}$ and $\left.3^{\prime}-\mathrm{H}\right)$. The GC-MS measurements gave us none result of $\left.\mathrm{MS}\right) ; v(\mathrm{KBr}) / \mathrm{cm}^{-1}$ : 3381 (N-H, br, w), 3071 and 3023 (C-H, sharp doublet, w); UV (DMSO): maxima observed at 266, 306, $422 \mathrm{~nm}$. Anal. Calcd for $\mathrm{C}_{40} \mathrm{H}_{22} \mathrm{~N}_{4}: \mathrm{C}, 86.00 ; \mathrm{H}$, 3.97; N, 10.03. Found: C, $86.29 \pm 0.49 ; \mathrm{H}, 3.88 \pm 0,30 ; \mathrm{N}, 9.82 \pm 0.48$.

Data for dibenzo[f,h]pyrido[2,3-b]quinoxaline: yield (1.63 g, 88\%) Mp: $213{ }^{\circ} \mathrm{C}$. For analysis, the pure product was obtained after a chromatographic column with toluene/dioxane $3: 1$ as the eluent. The product is difficult to solubilize and DMF was used as a solvent for the column deposit to limit this one. The product after elimination of the column solvent was washed with water to eliminate any DMF traces and after that filtrated and dried. ${ }^{1} \mathrm{H}$ NMR $\delta_{\mathrm{H}}(200 \mathrm{MHz}$; $\left.\left(\mathrm{CD}_{3}\right)_{2} \mathrm{SO} ; \mathrm{Me}_{4} \mathrm{Si}\right): 9.37 \mathrm{ppm}(1 \mathrm{H}, \mathrm{dd}, 4.1 \mathrm{~Hz}, 1.8 \mathrm{~Hz}, 10-\mathrm{H}), 9.34-9.24 \mathrm{ppm}(2 \mathrm{H}$, $\mathrm{m}, 4-\mathrm{H}$ and $5-\mathrm{H}), 8.84 \mathrm{ppm}(1 \mathrm{H}, \mathrm{d}, 8.4 \mathrm{~Hz}, 12-\mathrm{H}), 8.80 \mathrm{ppm}(2 \mathrm{H}, \mathrm{dd}, 8.5 \mathrm{~Hz}$, $1.8 \mathrm{~Hz}, 8-\mathrm{H}$ and $1-\mathrm{H}), 8.03 \mathrm{ppm}(1 \mathrm{H}, \mathrm{dd}, 8.5 \mathrm{~Hz}, 4.0 \mathrm{~Hz}, 11-\mathrm{H}), 7.98-7.82 \mathrm{ppm}$ $(4 \mathrm{H}, \mathrm{m}, 2-\mathrm{H}, 3-\mathrm{H}, 6-\mathrm{H}$ and $7-\mathrm{H})$. MS-EI $\mathrm{m} / \mathrm{z}: 281(\mathrm{M}, 100 \%), 280\left(\mathrm{M}^{-1}, 26\right)$, 282( $\left(\mathrm{M}^{+1}, 21\right), 140(20) \cdot v(\mathrm{KBr}) / \mathrm{cm}^{-1}: 3426(\mathrm{~N}-\mathrm{H}, \mathrm{br}, \mathrm{w}), 3071$ and $3021(\mathrm{C}-\mathrm{H}$, sharp doublet, w); UV (DMSO): maxima observed at 262, 314, $390 \mathrm{~nm}$. Anal. Calcd for $\mathrm{C}_{19} \mathrm{H}_{11} \mathrm{~N}_{3}$ : C, 81.12; H, 3.94; N, 14.94. Found: C, $81.75 \pm 0,88 ; \mathrm{H}$, $4.20 \pm 0,29 ; \mathrm{N}, 14.05 \pm 0,77$. 